\title{
Status and Distribution of Micronutrients in Vertisol for Teff and Nitisol for Wheat Growing Area of West Showa Zone
}

\author{
Zeleke Obsa, Girma Chala, and Mihretu Bedasa \\ Holeta Agricultural Research Center, PO BOX 31, Holeta , Ethiopia
}

\begin{abstract}
The study was conducted to evaluate soil micronutrients status and to investigate soil-plant nutrient relationships, in West Showa Zone, during 2018/2019 GC. A total of 30 samples randomly taken from each field of wheat and teff-growing fields were used for soil and plant sample collection. The extractable micronutrients were determined using DTPA soil test extraction procedure. The study shows that mean values micronutrients were in the order of $\mathrm{Fe}>\mathrm{Zn}>\mathrm{Mn}>\mathrm{Cu}$ at both study area of soil types. Descriptive statistics was carried out to reveal the soil - plant relationships. The soil was low Fe (201.06ppm) at Welmera and medium (191.19ppm) at Adaberga and sufficient in $\mathrm{Zn}(76.8 \mathrm{ppm}$ at Welmera) and $(76.29 \mathrm{ppm})$ at Adaberga, while, Mn was found in deficient categories. The concentration of extractable micronutrient was found in the order of $\mathrm{Fe}>\mathrm{Zn}>\mathrm{Mn}>\mathrm{Cu}$. The concentration of $\mathrm{Fe}$ (318.29ppm), Zn (6.73ppm), and Mn (53.27ppm) were recorded from wheat tissue. High concentration of Fe (ppm) at both site and sufficient in $\mathrm{Zn}, \mathrm{Mn}$ and $\mathrm{Cu}$ concentration was recorded from plant tissue of wheat. The soil will not require supplementary application of Fe nutrient. Since concentration of Fe were above critical limits of arable land and a supplementary application of $\mathrm{Zn}, \mathrm{Mn}$ and $\mathrm{Cu}$ nutrient were not strongly recommended to enhance the soil fertility status and soil productivity of the area.
\end{abstract}

Keywords: concentration; micronutrient; nitisoil; vertisol; soil-plant relationship

DOI: $10.7176 / \mathrm{JEES} / 11-12-01$

Publication date: December $31^{\text {st }} 2021$

\section{Introduction}

Micronutrients are important elements that are assimilated by plans in trace amount (Mulugeta et al., 2005). Seven plant nutrients, i.e., boron $(\mathrm{B})$, chloride $(\mathrm{Cl})$, copper $(\mathrm{Cu})$, iron $(\mathrm{Fe})$, manganese $(\mathrm{Mn})$, molybdenum $(\mathrm{Mo})$, and zinc $(\mathrm{Zn})$, required by plants in very small quantities, are known as micronutrients (Rashid and Ryan, 2004). Soil micronutrient deficiencies not only reduce crop productivity, but also low micronutrient concentrations in plant food adversely affect human health and well-being. Increased in crop yields from application of micronutrient nutrient source occurred in many parts of the world (Fageria et al., 2011). They further stated that, there is growing awareness that micronutrient deficiencies may limit crop yields even though plants require exceedingly small amounts. In Ethiopia, micronutrients investigation has received little attention since it was considered that there was adequate level of micronutrient (EthioSIS, 2015). In the central highland of Ethiopia, soil fertility is low to very low and the effect of liming on zinc showed that there was an adequate indication to warrant a further investigation into the possible deficiency of $\mathrm{Zn}$ in soil (Dibabe et al, .2007). Fanuel et al, (2016) found that the contents of Fe and Mn were usually at an adequate level while Mo and $\mathrm{Zn}$ contents were variable.

Different factor affects the soil-plant relationship. Thus, a combined use of soil and plant analysis is believed to evaluate the complex interaction, get an accurate image of limiting nutrients and design corrective actions (Aref 2011). Ideally, soil and tissue nutrient concentrations are expected to be positively correlated for most nutrients (Fageria et al., 2011). Nevertheless, factors such as soil nutrient level, soil conditions, genotype or climate influence the required nutrient concentrations in plants (Taye and Yifru, 2010, EthioSIS, 2015). In order to improve nutrient application, and crop yield, knowledge on soil-plant relationship has great practical importance. However, wide surveys dealing with soil-plant nutrient relationship are insufficient. Thus, it is hypothesized that most of the intensively cultivated fields under low- to no-input systems in west shewa area are likely to be deficient in micronutrients. The objective of this study was, therefore, to evaluate soil and plant nutrient status and investigate soil-plant nutrient relationships on different soil types.

\section{Materials and methods}

\subsection{Description of the study area}

The study was conducted in Welmera and A/berga Districts of west showa zone, Oromia regional state during $2017 / 18$.

Welmera district is located between $09^{\circ} 00^{\prime} 3$ "N latitude and $38^{\circ} 00^{\prime} 20^{\prime \prime}$ E longitude and at an altitude of about 2400 meter above sea level (masl). The rainfall is bimodal with average annual rainfall of $1041.4 \mathrm{~mm}$, about $85 \%$ of which is received from June to September and the rest from January to May. The average minimum and maximum air temperature is 6.7 and $21.7^{\circ} \mathrm{c}$ respectively with relative humidity of $58.7 \%(\mathrm{HARC}, 2016$ and 2017). The environments are seasonally humid and the major soil type of the area is Eutric Nitisols (FAO classification).

Ada berga district is situated at the latitude of $09^{\circ} 03^{\prime} \mathrm{N}$, longitude of $38^{\circ} 30^{\prime} \mathrm{E}$ and an altitude of 2450 m.a.s.1. 
the experimental site has a mean annual rainfall of $1044 \mathrm{~mm}$, mean maximum temperature $23.2^{\circ} \mathrm{C}$, mean minimum temperature $7.8^{\circ} \mathrm{C}$ and mean relative humidity $61.6 \%$.The -main rainy season is from June to September and accounts for $70 \%$ of the annual. Eutric nitisols associated with humic nitisols are the most prevalent soils (FAO classification).

Dendi district, is situated at the latitude of $9^{\circ} \mathrm{N}$ and latitude $3^{\prime} 30^{\prime \prime} \mathrm{E}$. The topography is flat land situated at an altitude of 2200 ma.s.l. The soil in the study area is predominantly Vertisol. The area has a bimodal rainfall pattern, with the main rain from June to September and short rain from February to April. The long term (30 years) average annual rainfall, maximum and minimum temperatures are $1094.95 \mathrm{~mm}$ and, $24.6^{\circ} \mathrm{C}$ and $8.4^{\circ} \mathrm{C}$ respectively (Weather data from Ginchi sub center),

\subsection{Farming Systems of the Study Areas}

The farming systems in the study area are mixed crop-livestock production and mainly based on continuous cultivation with infrequent fallow periods. In the area wheat and barley is the dominant crop. In addition, potato and, teff are also some of the major crops growing at Welmera and Ada Berga districts. Whereas, at Dendi district, tef (Eragrostis tef) is one of the major crops complemented by other cereals such as maize and chickpea, grasspea and wheat are also some of the major crops growing.

\subsection{Soil and plant sampling and analysis}

A total of 30 samples randomly taken from each field of wheat and teff-growing fields were used for soil and plant sample collection. From each field, relevant information regarding topography, cropping history, soil fertility management practices and estimated yield was recorded using a short structured questionnaire.

\subsection{Soil sampling and analysis}

Soil samples were taken from 0-20 cm depth. About 10 subsamples from each field were taken to form $1 \mathrm{~kg}$ composite sample. After soil processing (drying, grinding and sieving), soil chemical properties their micronutrient contents was analyzed. Micronutrients $(\mathrm{Fe}, \mathrm{Mn}, \mathrm{Zn}$ and $\mathrm{Cu}$ ) were extracted from the soil samples with DTPA as described by Lindsay and Norvell (1978). All micronutrients extracted with DTPA were measured by atomic absorption spectrophotometer.

\subsection{Plant sampling and analysis}

For the determination of mineral nutrients, leaves adjacent to the uppermost mature or flag leaves were considered. The uppermost mature or flag leaves are best indicators of mineral nutrients (Campbell and Plank 2000; Ramulu and Raj 2012) and about 30 to 40 leaves/field were collected from different plants. These samples were homogenized to make one representative sample for a field. Leaves were first washed with distilled water, oven dried at $70^{\circ} \mathrm{C}$ for $48 \mathrm{hr}$ to a constant weight. Thereafter, samples were ground and stored in airtight plastic bags. From the composite samples, subsamples were taken for analyzing micronutrients $(\mathrm{Cu}, \mathrm{Fe}, \mathrm{Mn}$ and $\mathrm{Zn})$. The tissue analysis was carried out at HARC soil and plant analysis Lab. in accordance with the procedures indicated in Sahlemedhin and Taye (2000). Plant digests using concentrated nitric acid $\left(\mathrm{HNO}_{3}\right)$ and $30 \%$ hydrogen peroxide $\left(\mathrm{H}_{2} \mathrm{O}_{2}\right)$ were prepared to extract and analyze $\mathrm{Cu}, \mathrm{Fe}, \mathrm{Mn}$ and $\mathrm{Zn}$ using by atomic absorption of spectrophotometer.

\subsection{Statistical analysis}

Descriptive statistics was carried out to reveal the soil - plant relationships. Correlation analysis was performed to assess the relationships between soil and plant nutrient contents and it was considered as a good measure for judging the reliability of the results.

\section{RESULTS AND DISCUSSION}

\subsection{Wheat and teff production and soil characteristic}

The survey result revealed that wheat and teff cultivation in the sampled fields was carried out on varied by soil types. Wheat and teff production is based on continuous cultivation with little fallow periods. The major crops that are commonly grown on Vertisols in Ethiopia are teff. However, cereal-dominated cropping systems, aimed at meeting farmers' subsistence requirements, coupled with low usage of chemical fertilizers have led to widespread depletion of soil nutrients in the major cereal crops growing regions of the country. Heavy rains during the early part of the main cropping season (June to August) also cause substantial soil nutrient losses due to intense leaching and erosion on Nitisols and denitrification on frequently water-logged Vertisols. For managing soil fertility, farmers have been using DAP and urea fertilizers up to 2007. Then after NPS and NPSB was replaced. NPS and NPSB fertilizer was applied at higher rates than urea. In the surveyed fields, NPS and NPSB application on the sampled wheat and teff fields varied. The wider range of fertilizer use implies soil fertility management differences among wheat and teff -growing farmers. 


\subsection{Status extractable micronutrients in nitisols and vertisols}

Brady and Weil (2002) indicated that the solubility, availability and plant uptake of micronutrient cations $(\mathrm{Cu}, \mathrm{Fe}$, $\mathrm{Mn}$ and $\mathrm{Zn}$ ) are more under acidic conditions. The concentration of extractable micronutrients were found to be $\mathrm{Fe}>\mathrm{Zn}>\mathrm{Mn}>\mathrm{Cu}$ at both study sites. By comparing the extractable micronutrients Fe in soil at welmera (Fig 1) and at Adaberga (Fig 2) was found in range of medium soil fertility classes (201.06 ppm) and (191.19ppm). As shown in figure 1 and 2, the mean and median value of extractable of $\mathrm{Zn}$ was $76.8 \mathrm{ppm}$ at Welmera and $76.29 \mathrm{ppm}$ at Adaberga was found sufficiently level categories.

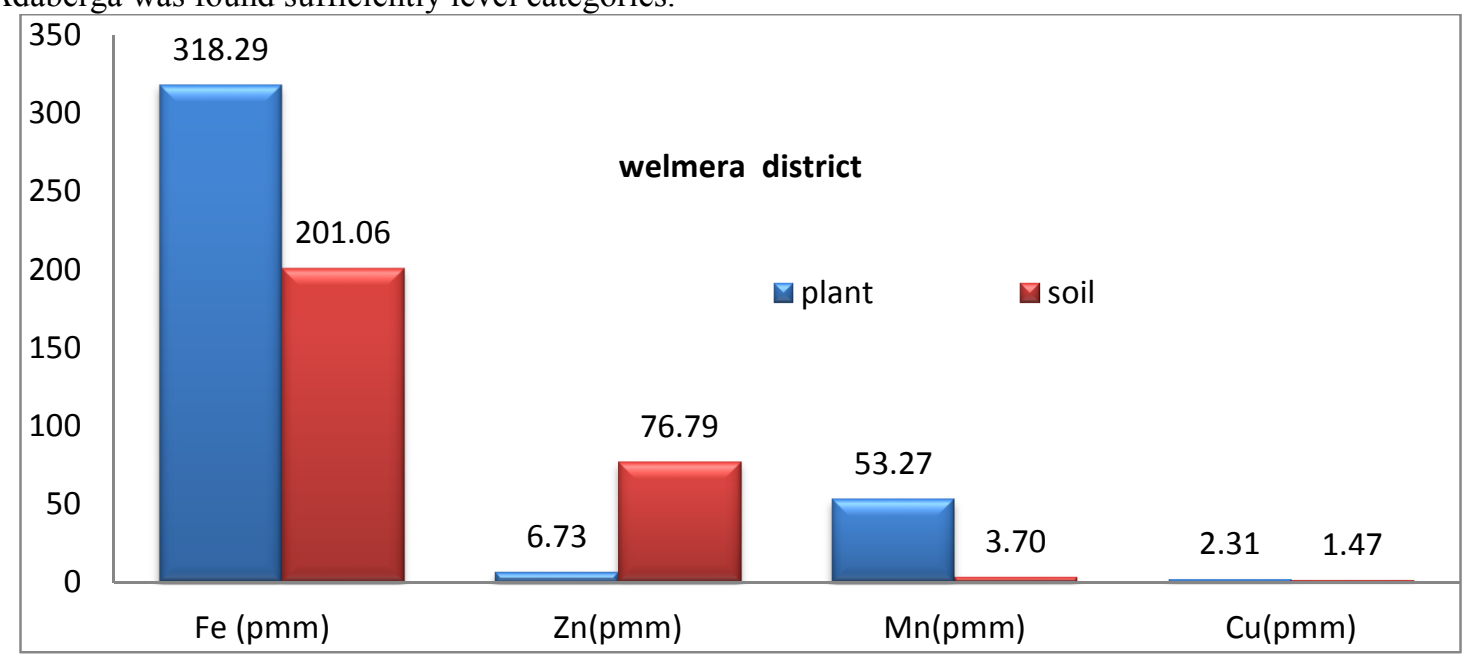

Figure 1. Micronutrients concentration in plant and in soil of wheat growing fields at welmera districts.

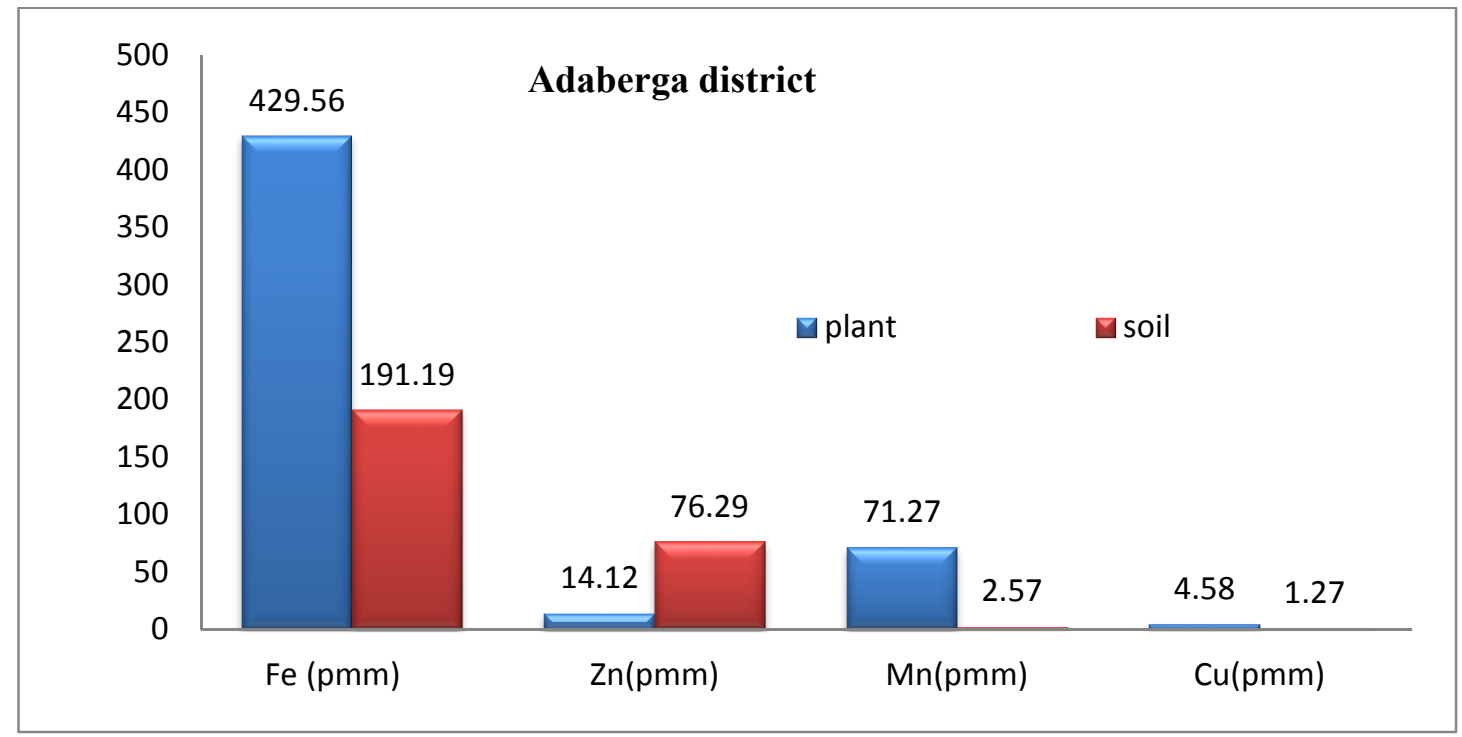

Figure 2. Micronutrients concentration in plant and in soil of wheat growing fields at Adaberga districts

Whereas, Mn (ppm) content of the study sites were found in deficient level .Accordingly, high level of Fe and $\mathrm{Zn}$ can reduce $\mathrm{Mn}$ and it will be enhanced by addition of acid causing $\mathrm{NH}_{4}^{+}$to soil and the availability of thus micronutrients increased due to leaching losses, increased solubility, sorption anions. In general soils which are dominated by acidic soil (nitisol ) areas, the deficiency of $\mathrm{Zn}$ and Fe is mostly not expected, whereas deficiency of $\mathrm{Cu}$ was found in oxisol areas( nitisol) (Aref ,2011 and Fanuel et al ,2016).

Similarly, significant variation was observed in Vertisols (figure 3). The concentration of EDTA extractable micronutrients in vertisols were in order of $\mathrm{Fe}>\mathrm{Zn}>\mathrm{Mn}>\mathrm{Cu}$. As rated by Jones and Benton (2003) micronutrients content indicates that medium in Fe (80.29ppm), sufficiency level of $\mathrm{Zn}$ (39.56ppm) and very low level in Mn and $\mathrm{Cu}$ (figure 3.) According to the fertility classes suggested the mean value of extractable Fe and Mn in the study area indicates that, there is no as such problem of soil fertility regarding available Fe and Mn. (Hazelton, 2007) observed that the total $\mathrm{Zn}, \mathrm{Mn}$ and Fe contents of the at all sites of his study area were comparable Vertisols at all sites of his study area were comparable and on most cases higher than values reported for most Vertisols elsewhere. These results are supported by the findings of Sanwal (2008) and Nandapure et al. (2011). 


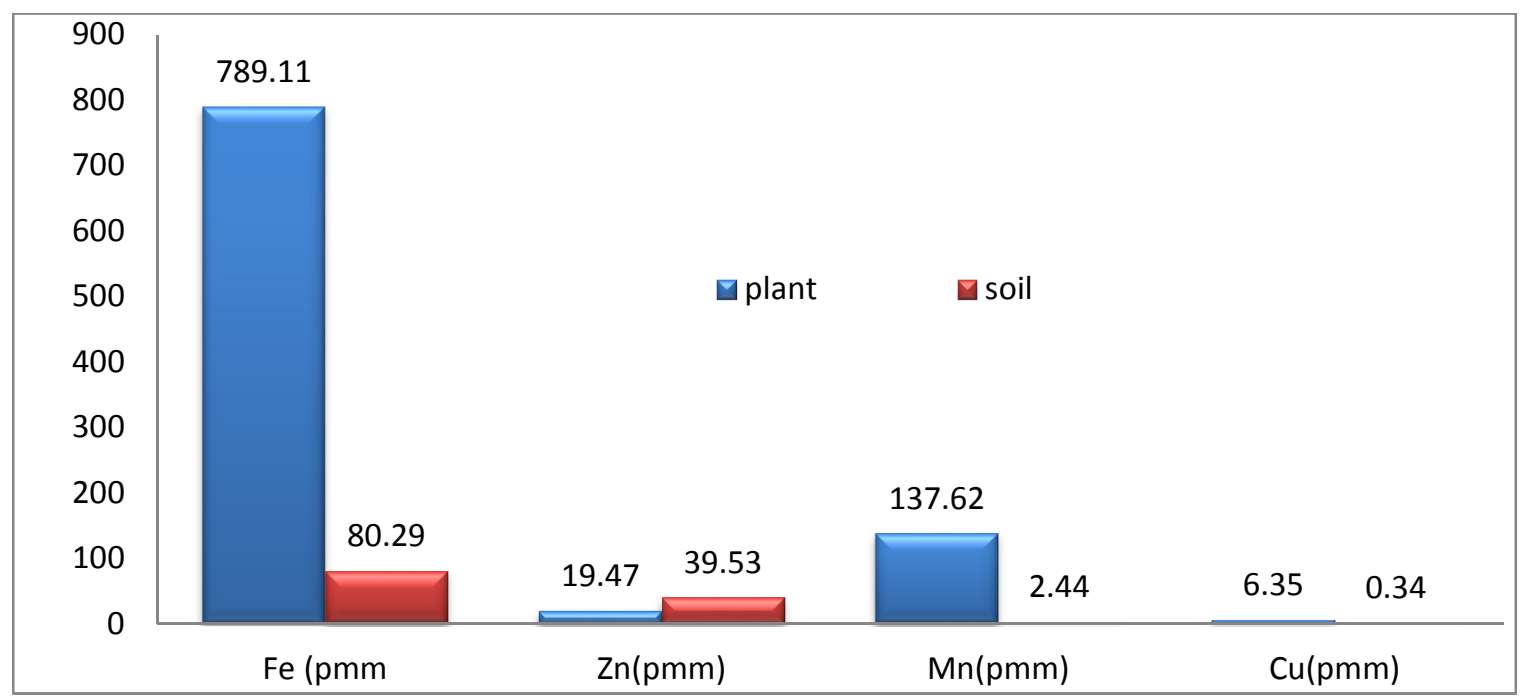

Figure 3. Micronutrients concentration in plant and in soil of teff growing field at Dendi District.

\subsection{Status of micronutrients in plant tissue of wheat (nitisols) and teff (Vertisol)}

There existed variability among micronutrient concentrations of wheat leaves. The mean concentration of $\mathrm{Fe}$ (318.29ppm), $\mathrm{Zn}(6.73 \mathrm{ppm}), \mathrm{Mn}(53.27 \mathrm{pmm}), \mathrm{Cu}(2.3 \mathrm{pmm})$ were recorded from wheat tissue (fig 1). Similarly, the mean concentration of $\mathrm{Fe}(429.56 \mathrm{ppm}), \mathrm{Zn}(14.12 \mathrm{ppm}), \mathrm{Mn}(71.27 \mathrm{pmm})$ and $\mathrm{Cu}(4.58 \mathrm{pmm})$ were recorded(fig 2). High concentration of $\mathrm{Fe}(\mathrm{pmm})$ was recorded from both sites while sufficient micronutrient $(\mathrm{Zn}, \mathrm{Mn}, \mathrm{and} \mathrm{Cu})$ concentration in the plant tissue noted as by indicated by Schwab et al. (2007) and Fageria, Baligar, and Jones (2011).Whereas, the mean concentration of Fe (789.11 ppm), Zn (19.47ppm), Mn (137.62ppm), and Cu (6.4ppm) were recorded from plant tissue of teff (fig 3$)$. Excess concentration of Fe (789.11ppm) and high concentration of Mn (137.62ppm) were recorded from the study sites, whereas sufficient micronutrient ( $\mathrm{Zn}$, and $\mathrm{Cu}$ ) concentration in the plant tissue were recorded as indicated by Schwab et al. (2007) and Fageria, Baligar, and Jones (2011).

\subsection{Relationship between Soil nutrients and plant nutrients}

In order to evaluate whether a particular nutrient in the wheat plant tissue is generally in similar trends with soil nutrient status, a simple correlation analysis was performed (Table 1, 2\&3). Positive and negative associations were also observed between micronutrients (Table 1, 2\&3). Accordingly, Fe content was significant and positive correlation with $\mathrm{Fe}(\mathrm{r}=0.39), \mathrm{Zn}(\mathrm{r}=0.39)$, and negative correlation with $\mathrm{Mn}(\mathrm{r}=-0.4)$ of the soil (Table 1). Similarly, the Fe content in wheat tissue was significant and positive correlated with $\mathrm{Fe}(\mathrm{r}=0.46)$ and negatively correlated with $\mathrm{Mn}(\mathrm{r}=-0.4)$ of the soil (Table 2$)$.

Table 1.The relationship between soil and plant tissues of wheat at Welmera District

\begin{tabular}{|c|c|c|c|c|c|c|c|c|}
\hline & \multicolumn{4}{|c|}{ Plant } & \multicolumn{4}{|c|}{ Soil } \\
\hline & $\mathrm{Fe}$ & $\mathrm{Zn}$ & $\mathrm{Mn}$ & $\mathrm{Cu}$ & $\mathrm{Fe}$ & $\mathrm{Zn}$ & $\mathrm{Mn}$ & $\mathrm{Cu}$ \\
\hline Fe in plant & 1 & & & & & & & \\
\hline $\mathrm{Zn}$ in plant & $0.8 * *$ & 1 & & & & & & \\
\hline Mn in plant & $0.589 * *$ & $0.46^{*}$ & 1 & & & & & \\
\hline $\mathrm{Cu}$ in plant & $0.89 * *$ & $0.67 * *$ & $0.68 * *$ & 1 & & & & \\
\hline Fe in soil & $0.39^{*}$ & $-0.4^{*}$ & -0.12 & -0.23 & 1 & & & \\
\hline $\mathrm{Zn}$ in soil & $0.39 *$ & $0.35 *$ & 0.03 & -0.28 & 0.47 & 1 & & \\
\hline Mn in soil & $-0.4^{*}$ & $-0.43^{*}$ & -0.13 & $-0.3 *$ & $0.57 * *$ & $0.49 * *$ & 1 & \\
\hline $\mathrm{Cu}$ in soil & 0.27 & -0.17 & -0.2 & -0.35 & $0.03 *$ & $0.48^{*}$ & $0.38^{*}$ & 1 \\
\hline
\end{tabular}

$*$, and $* *$ significant at $\mathrm{p}<0.01$ and 0.001 , respectively. 
Table 2.The relationship between soil and plant tissues of wheat at A/berga District

\begin{tabular}{|c|c|c|c|c|c|c|c|c|}
\hline & \multicolumn{4}{|l|}{ Plant } & \multicolumn{4}{|l|}{ Soil } \\
\hline & Fe & $\mathbf{Z n}$ & Mn & $\mathbf{C u}$ & $\mathbf{F e}$ & Zn & Mn & $\mathrm{Cu}$ \\
\hline Fe in plant & 1 & & & & & & & \\
\hline Zn in plant & 0.3 & 1 & & & & & & \\
\hline Mn in plant & $0.64 * *$ & $0.5 * *$ & 1 & & & & & \\
\hline $\mathrm{Cu}$ in plant & -0.2 & 0.2 & -0.1 & 1 & & & & \\
\hline Fe in soil & $0.46^{*}$ & -0.09 & -0.36 & 0.05 & 1 & & & \\
\hline Zn in soil & 0.23 & -0.09 & 0.06 & 0.22 & 0.09 & 1 & & \\
\hline Mn in soil & -0.47 & -0.04 & 0.28 & 0.06 & 0.89 & 0.21 & 1 & \\
\hline $\mathrm{Cu}$ in soil & 0.34 & -0.21 & -0.28 & 0.17 & $0.73 * *$ & 0.28 & 0.76 & 1 \\
\hline
\end{tabular}

$*$, and $* *$ significant at $\mathrm{p}<0.01$ and 0.001 , respectively.

In vertisols of teff growing fields, Fe content in plant tissue was significant and positively correlated with $\mathrm{Zn}(\mathrm{r}=0.51)$, non-significant and positively correlated with $\mathrm{Fe}(\mathrm{r}=0.22)$ and non-significant and positively correlated with $\mathrm{Cu}(\mathrm{r}=0.3)$ in soil (Table 3). These results are supported by the findings of Sanwal (2008) and Nandapure et al. (2011).

Table 3. The relationship between soil and plant tissues of teff at Dendi District

\begin{tabular}{lllllllll}
\hline & \multicolumn{7}{l}{ Plant } & \multicolumn{7}{c}{ Soil } \\
\cline { 2 - 7 } Fe in plant & Fe & $\mathrm{Zn}$ & $\mathrm{Mn}$ & $\mathrm{Cu}$ & $\mathrm{Fe}$ & $\mathrm{Zn}$ & $\mathrm{Mn}$ & $\mathrm{Cu}$ \\
\cline { 2 - 7 } Zn in plant & -0.25 & 1 & & & & & & \\
Mn in plant & 0.03 & -0.12 & 1 & & & & & \\
Cu in plant & -0.11 & -0.03 & -0.15 & 1 & & & & \\
Fe in soil & 0.22 & 0.20 & -0.21 & -0.3 & 1 & & \\
Zn in soil & $0.51^{*}$ & -0.07 & 0.18 & 0.2 & -0.29 & 1 & & \\
Mn in soil & -0.01 & 0.10 & 0.15 & -0.15 & $0.56^{*}$ & -0.02 & 1 \\
Cu in soil & 0.3 & -0.04 & -0.11 & -0.1 & $0.53^{*}$ & -0.06 & 0.39 & 1 \\
\hline
\end{tabular}

*, and $* *$ significant at $\mathrm{p} \leq 0.01$ and 0.001 , respectively.

\section{Summary and conclusion}

In terms of soil fertility, one cannot talk about the complete fertility of soils in the absence of micronutrients. Though they are required in trace and they are as essential as the macronutrients. Unfortunately, there is no enough information on micronutrients of Ethiopian soils in general and the study area in particular. The traditional soil fertility management practices were not adequate to replenish the high amount of nutrients mined by the demanding wheat crop. This led to low levels of some micronutrients in the soil. This was partly reflected in the leaf or tissue test results. In addition, the influence of soil nutrient imbalances on the uptake of nutrients was observed. The overall result obtained is indicative of the existing situations. Furthermore, it also showed that soil test should be complemented with tissue analysis. Therefore, soil management practices and fertilizer application that would address observed nutrient limitations of micronutrients is recommended for realizing better yield. It is evidence that from this study, the extractable Fe values was high, $\mathrm{Mn}$, and $\mathrm{Zn}$ value sufficient at both study sites. From this study, it can be concluded that, almost all soils of the study area were low in extractable $\mathrm{Zn}$ and $\mathrm{Cu}$. As a conclusion, we remark that locally tested and adopted critical levels for micronutrient requirement to be settled in order to make sure that these findings were well established. Therefore, soil management practices and fertilizer application that would address observed nutrient limitations of micronutrients is recommended for realizing better yield. In addition, future research should focus on assessing the availability of these and other micronutrients by collecting large number of soil and plant samples and conducting field trials in the area. In addition, further studies considering other all cereal crop and soil type is suggested.

\section{Reference}

Aref, F. 2011. Concentration of zinc and boron in corn leaf as affected by zinc sulfate and boric acid fertilizers in a deficient soil. Life Science Journal 8 (1):2-11

Campbell, C. R., and C. O. Plank. 2000. Reference sufficiency ranges of corn. In Reference sufficiency ranges for plant analysis in the southern region of the United States C. Southern cooperative series bulletin \#394, ed. R. Campbell. Raleigh, NC: North Carolina Department of Agriculture and Consumer Services Agronomic Division.

Dibabe, A., T. Bekele, and Y. Assen. 2007. The status of micronutrient in Nitisols, Vertisols, Cambisols and Fluvisols in Major maize, wheat, teff and citrus growing areas of Ethiopia. Proceedings of the workshop on status of micro nutrient, Addis Abeba, Ethiopia, December 27, Ethiopian Institute of Agriculural Research, $28-39$. 
EthioSIS (Ethiopia Soil Information System). 2014. Soil fertility status and fertilizer recommendation atlas for Tigray regional state, Ethiopia. Addis Ababa, Ethiopia, July 2014

EthioSIS (Ethiopia Soil Information System). 2015. Ethiopian Agricultural Transformation Agency.http://www.ata.gov.et/highlighted-deliverables/ethiopian-soil-information-system-ethiosis/.

Fageria, N. K., V. C. Baligar, and C. A. Jones. 2011. Growth and mineral nutrition of field crops, 3rd ed. Boca Raton, FL USA: CRC Press.

Fageria,N.K.,andV.C.Baligar.2005.Enhancingnitrogenuseefficiencyincropplants.AdvancesinAgronomy88:97185.

Fanuel Laekemariam, Kibebew Kibret, Tekalign Mamo \& Heluf Gebrekidan .2016. Soil-Plant Nutrient Status and their Relations in Maize-Growing Fields of Wolaita Zone, Southern Ethiopia, Communications in Soil Science and Plant Analysis, 47:11, 1343-1356

Fanuel Laekemariam. 2015. Soil spatial variability analysis, fertility mapping and soil plant nutrient relations in Wolaita Zone, Southern Ethiopia. PhD dissertation. Graduate School, Haramaya University, Harar, Ethiopia.

Hazelton, P. and B. Murphy, 2007. Interpreting soil test results: What do all the numbers mean? 2nd Edition. CSIRO Publishing. 152p. 7.

Jones, J.B., 2003. Agronomic Handbook: Management of Crops, Soils, and Their Fertility. CRC Press LLC, Boca Raton, FL, USA. 482p.

Lindsay, W.L. and Novell, W.A. 1978. Development of a DTPA soil test for zinc, iron, manganese, Litz, R.E. 2000. Botany, Production and CABI. UK. London. PP. 184-185.

Murphy K, Hoagland L, Reeves P, Jones S. Effect of cultivar and soil characteristics on nutritional value in organic and conventional wheat. 16th IFOAM Organic World Congress, Modena, Italy, 2008.

Nandapure SP, Sonune BA, Gabhane VV, Katkar RN, Patil RT. Influence of long term fertilization on micronutrients availability, their uptake and productivity of sorghum-wheat sequence under semi-arid condition on a Vertisol. Crop Research (Hisar). 2011; 42(1/2/3):35-39.

Ramulu, C., and G. B. Raj. 2012. Nutrient status and extent of their deficiencies in maize crop a survey in three districts of Andhra Pradesh. Journal of Research ANGRAU 40 (1):16-20.

Rashid, A and J. Ryan. 2004. Micronutrient Constraints to Crop Production in Soils with Mediterranean-Type Characteristics: A Review. Journal of Plant Nutrition 27 (6): 959-975.

Sahlemedhin, S., and B. Taye. 2000. Procedures for soil and plant analysis. Technical paper 74, National soil research center, Ethiopian Agricultural Research Organization, Addis Abeba, Ethiopia.

Schwab, G. J., C. D. Lee, R. Pearce, and W. O. Thom. 2007. Sampling plant tissue for nutrient analysis. University of Kentucky Cooperative Extension. AGR-92Loide V. 2004. About the effect of the contents and ratios of soil's available calcium, potassium and magnesium in liming of acid soils. Agronomy Research 2 (1):71-82. 